\title{
Arctic grazing systems and industrial development: can we minimize conflicts?
}

\author{
David R. Klein
}

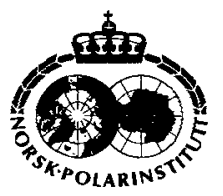

\begin{abstract}
The industrialized world is expanding its search for energy, minerals, timber and other resources into the Arctic and adjacent higher latitudes. Up to now, large-scale development projects in the Arctic and sub-Arctic have been few. We can, however, profit from experiences gained from several of these, including oil and gas exploration and development in Alaska and on Russia's Yamal Peninsula, the Norilsk metalurgical complex of Siberia, Alaska's Red Dog mine and others. Conclusions drawn from these experiences are that industrial impacts on Arctic grazing systems can be minimized if the following considerations guide their planning: 1) most of the large development projects that have been undertaken in the North have lacked adequate background information on the grazing systems that they might impact; 2) there needs to be recognition by industry and governments for the amount of time required to gather such information and provision made for this; 3 ) because types of impacts on northern grazing systems that may result from development projects vary depending on whether they involve mining, oil or gas, hydroelectric or other activities, each proposed project must be assessed independently; 4) cumulative effects of multiple projects, often sequentially developed, are seldom addressed by the responsible governments, thus planning for development of an individual project should be within the context of regional and long-range development planning; and 5) types and sources of contaminants entering northern ecosystems, threatening the health of northern residents, must also be a major focus of project assessment.
\end{abstract}

D. R. Klein, Institute of Arctic Biology, University of Alaska Fairbanks, Irving I Bldg., Fairbanks, AK 99775 7000, USA.

Historically, the lands of the Arctic and adjacent northern forests experienced few effects of the rapidly developing and expanding industrialized world to the south. But as a consequence of its demand for the energy, mineral, timber and other resources necessary to maintain its production and consumption of material goods, and its growth, the industrialized world is now expanding its search for resources into the Arctic and adjacent higher latitudes. Such efforts are designed to serve the interests of industry, with little understanding, appreciation or concern for the residents of the North, their cultural, social and economic wellbeing, and the natural environments which have sustained them. It is now time for governments in those countries with lands in the Arctic to establish collaboration with industry and residents of the
North to assure that northern development proceeds only when such activities can take place without major impacts detrimental to the northern environment and the residents dependent upon it.

Because of the logistic and engineering difficulties and associated high expenses involved in resource development and extraction in the North, only the larger energy and mining companies have the financial and other resources necessary to undertake northern development ventures. This may facilitate governmental assessment of potential environmental impacts, as well as social and economic influences on local residents prior to approval of proposed projects. Financial responsibility for this effort should be shared between industry and government. During development and production phases, governmental monitoring and 
enforcement of stipulations designed to minimize environmental and socio-economic impacts can be more feasibly dealt with than is the case for smaller scale, more widely scattered, projects. However, large industrial complexes, seeking a maximum return on their investments, have a record of mobilizing their considerable potential political influence on national and regional governments to oppose or constrain the imposition of environmental or other restrictions on their exploration, development and production activities.

\section{Learning from existing and proposed development projects}

Although large-scale development projects in the Arctic and sub-Arctic have been few in contrast to those at lower latitudes, there are several throughout the circum-Arctic region that have directly or indirectly influenced Arctic grazing systems, and from which much can be learned. They offer examples and experiences of value in assessing proposed new projects and for designing guidelines for their development to avoid unnecessary environmental, social and economic impacts. These past and current projects also point up inadequacies in the initial planning that in some cases have led to impacts that could have been avoided or minimized through more conscientious and comprehensive planning in advance of project approval. They also reveal the general lack of knowledge within governments and industry about ecosystems at high latitudes and of the human relationships to them.

\section{Alaska's Arctic oil development}

The discovery in 1968 of a giant oil reservoir at Prudhoe Bay in Alaska's Arctic led to a rush by the oil industry to construct a pipeline more than $1000 \mathrm{~km}$ across Alaska to an ice-free port to the south so that the oil could be transported to markets. However, construction of the pipeline and development of the oil field were delayed for nearly four years until land entitlement of Alaska natives and public land use issues could be resolved by the US Congress. The delay in development of this giant project was viewed by the oil industry with understandable frustration, whereas environmental organizations were vocal in their emphasis on the need for adequate assessment of environmental values at risk, demonstration by industry of adequacy of engineering design for Arctic conditions, and development of governmental stipulations and oversight to minimize impacts on the environment. Nevertheless, this delay before governmental authorization could be granted for pipeline construction allowed time for at least superficial environmental studies to be undertaken and for development of environmental stipulations for construction and operation of the pipeline and oil field designed to minimize impacts on the environment. It also allowed for settlement of Alaska Natives' claims to land and other entitlements, and for initiation of opportunities for Alaska Natives to derive economic benefit from the oil development.

In retrospect, industry, environmental interests, Alaska Natives and government all have recognized that the time that was available between oil discovery and initiation of pipeline and oil field construction resulted in substantial reduction of the environmental impacts associated with the project. Whereas the Prudhoe Bay oil field and associated TransAlaska Pipeline are now viewed as examples of large-scale energy development in the Arctic with low environmental impact, this assessment has to be viewed in the context of the times and the magnitude of the project. It is now apparent that there are unanticipated cumulative effects resulting from intensified and expanded oil field development involving proliferation of roads, pipelines and other oil field infrastructure. The consequences for seasonally resident caribou are displacement from calving grounds, obstruction of their movements to and from the coast during the insect season, and gradual abandonment of grazing areas within the oil field, with evidence of reduced body condition of adult females and lowered recruitment rates (Cameron et al. 1995). Experience gained since early development of the Prudhoe Bay field has led to design and layout of pipelines, roads and other oil field infrastructure so as to reduce the obstruction of movements of caribou and the degree of their abandonment of grazing areas. The complexity of the ecological relationships of caribou to their environment in this region of the Alaskan Arctic, nevertheless, is only now beginning to be realized.

\section{Proposed oil exploration and development in north-eastern Alaska}

The coastal plain of Alaska's Arctic National 
Wildlife Refuge has become the site of proposals for large-scale oil development. As a result, the US Congress provided for comprehensive studies to assess the environmental values present and possible impacts of oil development on them. Caribou of the Porcupine Herd, numbering ca. 130000 , and their ecosystem relationships were a major focus of these studies (US Fish and Wildlife Service 1982; Garner \& Reynolds 1983, 1984). Companion ecological studies were also carried out in Canada on this international caribou herd (Russell et al. 1993). Because of the comprehensive nature of these studies and the time made available for their completion, much has been learned about the importance of vegetation and its phenology in determining the seasonal patterns of use of the land by caribou, especially in relation to the importance of specific calving grounds and summer foraging areas. In addition, the relationship of the caribou to bears, wolves and other components of the ecosystems involved, including the humans who hunt and are dependent upon caribou, have been examined. As a result of this accumulation of detailed knowledge about an Arctic grazing system at the ecosystem level, the US National Science Foundation funded a project to develop a computer-based interactive model focused on the sustainability of the human communities that have long been dependent on the caribou and the ecosystems that support them. The information that has been gathered in these efforts, and the models of varying potential future community options, will be of the utmost value in empowering these northern peoples to have an equitable voice in authorizing oil development within the calving grounds and summering areas of the Porcupine Caribou Herd (Kruse 1999). Should oil development be permitted in the future, planning for the oil field and necessary pipelines and roads to minimize impacts on the caribou will be greatly assisted as a result of these efforts. Perhaps one of the most valuable outcomes of this example of a comprehensive study of an Arctic grazing system has been a recognition by the natural and social scientists and economists involved, and the native stakeholders in the system, of the complexity of the system and of the difficulty of modelling this complexity so that it will have predictive value. Those involved in this project have developed a sense of humility regarding our ability to fully understand Arctic grazing systems and the human role in their sustainability.
Gas exploration and development on the Yamal Peninsula

Exploration and development of extensive gas fields on the Yamal Peninsula of Russia, primarily during the 1980 s, while not yet in a production stage, progressed rapidly without assessment of surface values or the potential effects on them and the reindeer grazing system of the Nenets people who live in the area. Erosion of the sandy soils, once the protective vegetative cover had been lost through road and rail construction, exploration activities and careless use of off road vehicles on the tundra, has resulted in substantial damage and loss of grazing lands for the reindeer (Forbes 1997). Stocking levels of reindeer on the Yamal ranges, however, already exceeded their sustainability prior to the widespread effects of exploration and development of the gas fields; thus reindeer grazing pressure was intensified on the remaining areas undisturbed by the petroleum exploration activities. Extensive development activities on the Yamal Peninsula, because of its highly erodible soils and importance for reindeer grazing and the Nenets people dependent upon them, should have been preceded by comprehensive biological and sociological studies of the local grazing system. These could have provided the basis for assessing impacts of the proposed exploration and development activities, and for establishing guidelines and restrictions designed to avoid or minimize the impact. Similarly, knowledge could have been gained about the most appropriate methods of restoring vegetation to areas unavoidably disturbed or damaged in the exploration activities (Forbes 1997). Involvement of the Nenets reindeer herders in the planning process might also have made it possible to schedule development activities and locate transportation corridors to minimize their effects on seasonal movements and range use patterns of the reindeer, and to avoid displacement of the herders from traditional seasonal camp sites.

\section{The Norilsk metalurgical complex}

In the Taimyr region of north-western Siberia, development of the Norilsk metalurgical complex began in the 1930s. It is now the world's largest producer of nickel and also the world's largest point source of atmospheric pollution. Some aspects of this giant mineral extraction development have had direct impact on both the wild reindeer of the 
Taimyr Herd, numbering in excess of 500000 , and domestic reindeer in several herds throughout the region. The energy source for ore smelting and for power generation was originally coal, but by the late 1960s some hydroelectric power had become available and natural gas pipelines were constructed from the Messoyakha Field during 1969-1973. This resulted in some immediate reduction in sulfur dioxide and other atmospheric pollutants, but continued growth in the industrial complex increased the sulfur component of the discharge gases from $5 \%$ in 1981 to about $50 \%$ by 1989 (Vlasova et al. 1991). Construction of the first pipeline, and subsequent addition of parallel pipelines laid across the tundra, obstructed the movement of large numbers of the Taimyr wild reindeer on their annual migrations between their summer calving and grazing areas and their wintering areás. Some of the wild reindeer, unable to cross the pipelines, initially were deflected in their movements into the city of Norilsk and the associated mining and smelting complex. The large concentrations of reindeer stopped in their movements by the pipelines trampled and overgrazed lichens and other vegetation (Skrobov 1984). Attempts to provide crossings with ramps or underpasses met with only limited success. Eventually, through the construction of lead fences in conjunction with large lakes and other natural terrain features, the wild reindeer were deflected in their fall migration away from the pipelines and into new wintering areas, primarily in the Putorana Mountains. There, lichen ranges existed that had been abandoned years earlier as grazing lands of domestic reindeer when the Soviet government adopted a policy of collectivization of reindeer herding (Syroechkovskii 1995). Subsequently, areas west of the pipelines and the Yenisey River that had previously been important wintering areas for a portion of the Taimyr Herd were largely abandoned.

Heavy fallout of atmospheric pollutants in the downwind pollution plume from the metalurgical complex has occurred since development of the project (Klein \& Vlasova 1992). The pollutants include sulfur dioxide, nitrogen oxides and heavy metals; sulfur dioxide and nitrogen oxides are primary components of acid precipitation. The prevailing downwind pollution plume extends more than $200 \mathrm{~km}$ to the south and south-east, and the total affected area of more than 600000 ha had been of primary importance for winter grazing by both wild and domestic reindeer. The heavy fallout of pollutants in this area has resulted in widespread death of lichens or decrease in their growth rates, as well as of many of the vascular plants, thereby causing a major reduction in the ability of the area to support reindeer. Effects on vegetation and other ecosystem components of the heavy metals present in the fallout from the Norilsk atmospheric pollution are not known.

The Norilsk project, because of its magnitude, remoteness and location at $69^{\circ} \mathrm{N}$, was a truly pioneering engineering effort at a time when the rest of the world had not yet viewed such projects as feasible in the Arctic. Experience from this project, developed at a time in the young Soviet Union when government policy almost exclusively focused on resource extraction for expansion of the nation's industrial complex, demonstrates the consequences of undertaking large-scale development projects in the North without first assessing their impact on existing living resources. The problems experienced with both wild and domestic reindeer in the development and operation of the Norilsk metalurgical complex where unanticipated. They demonstrated the complexity of Arctic grazing systems in which freedom of movement of wild and domestic reindeer and caribou is essential for their access to, and use of, seasonal range components. They also demonstrated the sensitivity of lichens and other vegetation, so important as forage for reindeer and caribou, to damage, destruction and contamination from industrial pollution. In retrospect, it is obvious that if an understanding of the ecology of the wild reindeer existed at the time, pipeline routing, design and construction could have been altered to greatly reduce the subsequent impact on the reindeer. Similarly, if the seriousness of the pollution effects on lichens and other forage plants was understood at the time, an assessment of the potential loss of extensive areas of grazing lands, with the associated impact on the reindeer, herders and other reindeer users, could have been weighed against benefits of the project, perhaps justifying design changes and mitigation efforts.

\section{Alaska's Red Dog mine}

In north-western Alaska a large lead/zinc deposit has been developed in the past decade, employing more than 450 workers, many of whom are Inupiat people resident in that region. The mine complex is in the mountains some $60 \mathrm{~km}$ from the coast of the Chukchi Sea. To get the processed ore to the sea where it could be stockpiled for transport south by 
ship during the ice-free summer, a road has been constructed. The road transects the route of migration of a portion of the Western Arctic Caribou Herd during their twice annual movements to and from wintering areas to the south and calving and summering areas to the north. To prevent or minimize the possibility of obstructing the movements of these caribou, the Northwest Alaska Regional Native Corporation (NANA), who own the mineral rights, in conjunction with biologists of the Alaska Department of Fish and Game, have worked closely with the mining company. By prior agreement, when notified of groups of caribou approaching the road, the mining company restricts ore trucks and other traffic until the caribou have crossed. State biologists monitor the movements of the caribou and often can anticipate timing of the approach of caribou to the road. However, it is the Inupiat workers, with strong traditional appreciation for the caribou, who play the primary role in notifying the mining company of approaching caribou and the need to curtail road traffic (J. Dau, pers. comm.). This apparently successful effort in minimizing impact on caribou of this large mining development resulted from close cooperation between the regional native corporation, the mining company and state and federal agencies. Prior to approval of development of the project, a comprehensive assessment of possible environmental impacts was required, and plans were incorporated in the project design to minimize impacts to acceptable levels. In this case, residents in the region of the proposed development who would be most directly affected by it played a major role in determining levels of acceptability of project impacts, and development of efforts to minimize them. The policy worked out with the mining company, assuring that a high proportion of the workers were hired locally, has been a major factor accounting for the relative success of the project in avoiding impacts on caribou and their habitat.

\section{Diamond mining in the Canadian barren-grounds}

The discovery in this decade of major deposits of diamond-bearing rocks in the Canadian Arctic led to a rush by mining interests to establish numerous large-scale mines. The area of interest lies within the central Barren Lands, a vast region including northern fringes of the boreal forest and expanses of tundra extending hundreds of kilometres to the Arctic Ocean. Much of the range lands occupied by the Bathurst Caribou Herd, estimated at nearly
500000 animals, overlaps the area of potential diamond mining interest. The Bathurst Herd is an important subsistence resource to both Dene and Inuit peoples of the region who hunt them primarily in early fall as well as throughout the winter. Also, in the past a limited harvest quota of caribou for commercial sale has been allocated by the government of the Northwest Territories to indigenous residents.

Development of the diamond mines will require expansion of the limited road system previously developed primarily to access a few gold mines in the area. Some of the proposed new roads would cross caribou migration routes, portions of calving grounds, and summer and winter foraging areas. These roads would improve access to the caribou for subsistence hunting which now often requires long journeys by snowmobile to reach the animals in winter; however, the roads would also facilitate caribou poaching. Traffic on the roads however, may delay, disrupt or deflect movements of the caribou or cause abandonment of foraging areas close to the roads; dust blowing from the roads in open terrain can significantly impact adjacent plant communities (Forbes 1995; Auerbach et al. 1997). Proposed hydroelectric development to provide energy for mining would create impoundments, powerlines and additional roads. Although the Canadian government has committed itself to the concept of sustainable development in the Canadian North, the rapid pace of diamond mining development has not allowed for completion of comprehensive environmental assessment, designation of critical caribou habitat units requiring protection, and establishment of adequate guidelines for the mining industry to assure minimization of its impact on the environment.

\section{Hydroelectric development}

Large-scale hydroelectric plants are uncommon in the Arctic. Among the exceptions are northern Quebec and Labrador, where provincial government policy has been to harness large amounts of the potential hydroelectrical energy for export to the eastern United States, adjacent Ontario, and to support large-scale iron mining in the region. Large impoundments have flooded extensive areas, resulting in some loss of winter range of the large George River Caribou Herd and several smaller herds, and possible deflection of caribou from traditional migratory routes. In one instance of rapid release of large volumes of water from an 
impoundment into the Caniapiscau River, over 10000 caribou of the George River Herd were drowned at a traditional river crossing during the 1984 fall migration (Berkes 1988). An intensive effort by the Quebec government and local people was required to remove the decomposing carcasses of the drowned caribou from the river and its banks to prevent contamination of the river, which is the source of drinking water and fish used by the indigenous Cree people living further down river. At that time, the George River Caribou Herd was estimated at 600000 and the loss of 10000 from the herd and the relatively small proportion of winter range flooded by the impoundments appeared to have no significant effect on the continuing abundance of caribou. Roads built during construction of the impoundments were also intended to facilitate access by the Cree hunters to the caribou, however, much of the road system soon became unusable because of their lack of maintenance.

Fish in the impoundments, which had greatly expanded existing lake systems, were found to contain dangerously high levels of mercury. The mercury, present naturally in the rocky ground that was flooded, had leached into the reservoir waters and became incorporated into the aquatic life where it moved up the food chain, becoming concentrated in the fish. The fish had been of seasonal importance to the Cree people in the region; however, because of the high mercury levels in the fish which posed a health hazard if consumed, fishing in the reservoirs was discontinued.

Several large hydroelectric developments in northern Norway have resulted in loss of grazing area for domestic reindeer (Skogland \& Mølmen 1980; Reimers 1984). The impoundments have flooded grazing lands and in some cases have obstructed traditional movement routes of the reindeer. In a similar way, power transmission lines and pipelines associated with hydroelectric projects have required increased effort by the herders in moving the reindeer until the animals have adapted to these new features in the landscape. In a review of studies and experience with high voltage electric transmission lines and their effect on wild reindeer and other ungulates, Reimers et al. (1997) have concluded that follow-up studies have been inadequate to assess the possible effect of the lines on wild ungulates. They suggested specific research needed to address this question (see also Reimers et al. 2000 , this volume).

\section{Other types of development}

Other development activities that have encroached on, or are impacting, northern grazing systems include intensive forestry and tourism. The former has been most prevalent in northern Fennoscandia where impacts on domestic reindeer grazing systems have included damage to lichen forage through logging activities and scarification of soils following logging to facilitate regeneration of conifers (Helle \& Saastamoinen 1979). (Foresters, for their part, complain that young trees may be damaged by the reindeer [Skuncke 1969] and by the herders' snowmobiles.) In Finland, extensive areas of mires have been drained to convert them to forest production, thus reducing availability of these important summer grazing areas for both domestic and wild reindeer (Helle 1980).

Tourism, while offering the potential for economic benefits to reindeer herding and caribou hunting peoples, can also bring negative impacts to northern grazing systems (Skogland 1994). These impacts may include: disturbance by recreational skiers and hikers during calving and displacement of animals from grazing near heavily travelled trails; competition with resident subsistence hunters for caribou and wild reindeer by nonresident sport hunters; and construction of tourist facilities in or adjacent to critical reindeer and caribou habitats.

Much greater effort should be directed by the responsible governments toward assessing the impacts at high latitudes of forest practices and tourism on reindeer and caribou grazing systems. Since both the vegetation and the reindeer and caribou may be slow to respond to the effects of these industrial activities, studies of their effects should be initiated as soon as possible so that results are available before extensive expansion of these industries occurs in the North.

\section{General conclusions on minimizing impacts on reindeer/caribou grazing systems}

1) Although reindeer and caribou throughout their circumpolar distribution are a common species, no two populations of reindeer/caribou or their habitat relationships are identical. In fact, the species Rangifer tarandus is the most complex ecologically and evolutionarily among the deer family, 
and it shows wide adaptive variability to its environment throughout its circumpolar distribution. Therefore, although similarities exist between reindeer/caribou grazing systems that may help in assessing possible impacts of development and planning for their minimization, each grazing system must be considered unique when threatened by a proposed development project. Collection of detailed information about specific grazing systems is, therefore, essential before an adequate assessment of impacts on them of proposed development projects can be made and provision made for their minimization.

2) Background data on grazing systems is essential in planning for minimizing impacts of proposed development projects. This should include the history of population numbers of reindeer or caribou and their variation, changes that may have occurred in range use patterns or the vegetation, as well as the numbers of people dependent upon the reindeer and caribou for their livelihood, and their geographic distribution and degree of cultural and economic dependence on the animals. Much of this information is available in the traditional knowledge of the people who are dependent on the reindeer and caribou. Indigenous knowledge should be documented and analysed as a first step in assessing the extent of additional investigations needed to adequately understand the possible impacts of proposed development activities.

3) These environmental and sociological studies require extended periods of time for their completion. Responsible government agencies must allow sufficient time for completion of these studies prior to any decisions on project authorization. Political pressure generated by industry and business interests should not be allowed to constrain the time necessary for completion of the necessary environmental and sociological studies.

4) The relative importance of reindeer and caribou grazing systems to the people dependent upon them, economically, socially and culturally, is seldom adequately considered in the evaluation of impacts of proposed development projects and in planning for their minimization. It is therefore essential that the human role in northern grazing systems that may be affected by development projects be adequately assessed and documented, and that this information be of primary consideration in project assessment, approval and planning for impact minimization.
5) While each proposed development project should be assessed on the basis of its individual effect on the environment and the local people, it should also be assessed in relation to the cumulative effects when considered in association with other projects in the area, both existing and planned. This has often not been done.

6) The types of industrial development occurring in the North, be it oil and gas, mining, hydroelectric power generation, wood production or tourism, all vary in the types of impacts they may impose on northern grazing systems. Therefore, minimization of their impacts may require quite different approaches unique to the specific industry.

7) Contaminants resulting from industrial activities are of major concern to northern residents because they are slow to break down at low temperatures and they readily enter the food chains of northern ecosystems where they accumulate at higher trophic levels. Because northern residents are dependent upon the reindeer/caribou and other mammals and fish that may have accumulated these contaminants, their own health is at risk when contaminants enter northern ecosystems. Adequate handling and treatment of contaminants to assure their containment must be a major consideration in assessing and planning for development projects where contaminants are involved.

8) Global climate change, whether from human contribution to atmospheric carbon dioxide and other "greenhouse gases" or natural causes, appears to be most pronounced in portions of the Arctic. The pronounced warming trend in the north-western Canadian Arctic, northern Alaska and much of the Eurasian Arctic will complicate assessment of long-term effects of proposed development projects. It is therefore important that pilot investigations be undertaken to record the changes that may be occurring in Arctic vegetation and other ecosystem components as a consequence of global climate change. This information will be essential in differentiating between landscape level changes in northern ecosystems brought about by global climate change versus those that may be the result of local industry or heavy grazing pressure by semidomestic reindeer (Evans 1996) or their wild counterparts (Manseau et al. 1996).

We can conclude that it is possible to minimize conflicts between industrial development and Arctic grazing systems by using the experience gained from past development projects to avoid 
the mistakes of the past and to benefit from the successes. Each grazing system that may be affected by a proposed development project should be considered unique. Therefore, sufficient knowledge of the dynamics and biological functioning of the system must be obtained, using local knowledge sources and directed research, prior to making an assessment of the impacts of the project and designing the development to minimize impacts.

\section{References}

Auerbach, N. A., Walker, M. D. \& Walker, D. A. 1997: Effects of roadside disturbance on substrate and vegetation properties in Arctic tundra. Ecol. Appl. 7, 218-235.

Berkes, F. 1988: The intrinsic difficulty of predicting impacts: lessons from the James Bay hydro project. Environ. Impact Assess. Rev. 8, 201-220.

Cameron, R. D., Lenart, E. A., Reed, D. J., Whitten, K. N. \& Smith, W. T. 1995: Abundance and movements of caribou in the oilfield complex near Prudhoe, Alaska. Rangifer 15, 3-7.

Evans, R. 1996: Some impacts of overgrazing by reindeer in Finnmark, Norway. Rangifer 16, 3-19.

Forbes, B. C. 1995: Tundra disturbance studies. III. Short-term effects of aeolian sand and dust, Yamal Region, Northwest Siberia, Russia. Environ. Conserv. 22, 335-344.

Forbes, B. C. 1997: Anthropogenic tundra disturbance in Canada and Russia. In R. M. M. Crawford (ed.) Disturbance and recovery in Arctic lands. Pp. 365-379. Dordrecht: Kluwer Academic Publ.

Garner, G. W. \& Reynolds, P. E. (eds.) 1983: Update report, 1982. Baseline study of the fish, wildlife, and their habitats. Anchorage: US Fish and Wildlife Service.

Garner, G. W. \& Reynolds, P. E. (eds.) 1984: Update report, 1983. Baseline study of the fish, wildlife, and their habitats. Anchorage: US Fish and Wildife Service.

Helle, T. 1980: Sex segregation during calving and summer period in wild forest reindeer (Rangifer tarandus fennicus Lönn.) in eastern Finland with special reference to habitat requirements and dietary preferences. In E. Reimers et al. (eds.): Proceedings of the 2nd Reindeer/Caribou Symposium, Roros, Norway, 1979. Pp. 508-518. Trondheim: Direktorat for Vilt og Ferskvannsfisk (Directorate of Game and Freshwater Fish).

Helle, T. \& Saastamoinen, O. 1979: The winter use of food resources of semi-domestic reindeer in northern Finland. Commun. Inst. For. Fenn. 95, 1-27.
Klein, D. R. \& Vlasova, T. J. 1992: Lichens, a unique forage resource threatened by air pollution. Rangifer 12, 21-27.

Kruse, J. 1999: An approach to planning research. Paper presented at the International Workshop, the Human Role in Reindeer/Caribou Systems. Rovaniemi, 10-14 February 1999.

Manseau, M. J., Huot, J. \& Crête, M. 1996: Effects of summer grazing by caribou on composition and productivity of vegetation: community and landscape level. J. Ecol. 84, 503514.

Reimers, E. 1984: Virkninger av menneskelig aktivitet på rein og caribou. En lieraturstudie. (Effects of human activity on reindeer and caribou. A literature study.) VN Rapp. 9. Naturog Landskapsavdelingen, Norges Vassdrags- og Energidirektorat (NVE) (Nature and Env. Dept., Norwegian Water Resources and Energy Directorate).

Reimers, E., Boving, P. S., Coleman, J. E. \& Enger, P. S. 1997: Study proposal for determining effects of high voltage transmission line on behavioral ecology of wild reindeer. Biological Institute, University of Oslo.

Reimers, E., Flydahl, K. \& Stenseth, R. 2000: High voltage transmission lines and their effect on reindeer: a research programme in progress. Pol. Res. 19(1), 75-82.

Russell, D. E., Martell, A. M. \& Nixon, W. A. C. 1993: Range ecology of the Porcupine Caribou Herd in Canada. Rangifer, Spec. Issue 8.

Skogland, T. 1994: Villrein - fra urinnvåner til miljøbarometer. (Wild reindeer - from indigenous species to environmental indicator.) Oslo: Teknologisk Forlag.

Skogland, T. \& Mølmen, Ø. 1980: Prehistoric and present habitat distribution of wild mountain reindeer at Dovrefjell. In E. Reimers et al. (eds.): Proceedings of the 2 nd International Reindeer/Caribou Symposium, Roros, Norway, 1979. Pp. 130-141. Trondheim: Direktorat for Vilt og Ferskvannsfisk (Directorate of Game and Freshwater Fish).

Skrobov, V. D. 1984: Human intervention and wild reindeer. In E. E. Syroechkovskii (ed.): Wild reindeer of the Soviet Union. Pp. 90-94. New Delhi: Amerindian Press.

Skuncke, F. 1969: Reindeer ecology and management in Sweden. Biol. Pap. Univ. Alaska 8, 1-81.

Syroechkovskii, E. E. 1995: Wild reindeer. New Delhi: Oxonian Press.

US Fish and Wildlife Service 1982: Arctic National Wildlife Refuge coastal plain resource assessment - initial report. Baseline study of fish, wildlife, and their habitats. Anchorage: US Fish and Wildlife Service.

Vlasova, T. J., Kovalev, B. I. \& Filipchuck, A. N. 1991: Effects of point source atmospheric pollution on boreal forest vegetation of northwestern Siberia. In G. Weller et al. (eds.): Proceedings, International Conference on the Role of Polar Regions in Global Change, Fairbanks, Alaska, 1990. Pp. 423-428. Fairbanks: University of Alaska. 